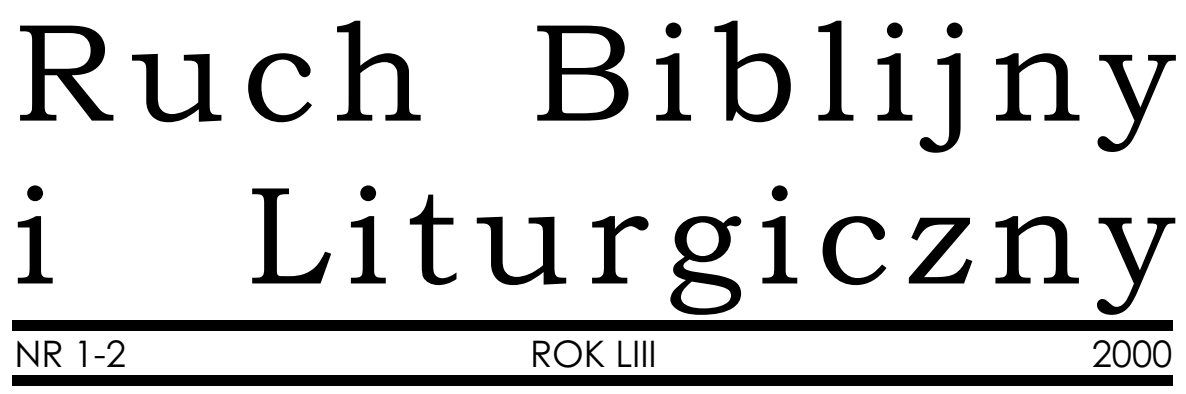

ks. Jerzy Chmiel

\title{
SZANOWNI CZYTELNICY!
}

Kwartalnik „Ruch Biblijny i Liturgiczny” w Roku Jubileuszowym 2000 wchodzi w swój 53. rok istnienia. Założony w 1948 roku, od ponad półwiecza służy polskiemu czytelnikowi informacjami na tematy biblijne i liturgiczne, zdobył także uznanie na arenie międzynarodowej, czego dowodem jest wpisanie go na listę czasopism indeksowanych przez filadelfijski Instytut Informacji Naukowej (ISI).

Pierwszy zeszyt w roku 2000 jest poświęcony pełnej bibliografii zawartości czasopisma w latach 1948-1998. Została ona podzielona na kilka części: są to artykuły, recenzje, dokumenty, bibliografie, teksty ogólne oraz teksty biblijne. Podział ten odpowiada układowi poszczególnych numerów RBL. Pozycje bibliografii zostały posortowane według nazwisk autorów tekstów lub ich tytułów, gdy podanie autora nie było możliwe.

Chcemy przypomnieć, że regularne otrzymywanie wszystkich numerów może zapewnić jedynie prenumerata. Zarówno prenumeratę, jak i pojedyncze numery można zamawiać lub kupować bezpośrednio w siedzibie Wydawnictwa UNUM, 31-002 Kraków, ul. Kanonicza 3, tel. (12) 42256 90. Zwracamy się przeto z prośbą do dotychczasowych Prenumeratorów o kontynuację, a wszystkich Czytelników zainteresowanych problematyką Biblii i liturgii o zamawianie nowych prenumerat. W ten sposób podtrzymacie Państwo istnienie czasopisma, które nie posiada żadnych zewnętrznych subwencji i jest zdane jedynie na swoich Czytelników.

Z najlepszymi życzeniami w Roku Jubileuszowym. 